\title{
Photovoltaics for Buildings: Key Issues in Pursuit of Market Readiness
}

Sheila J. Hayter, P.E.

National Renewable Energy Laboratory

Presented at the National Center for

Photovoltaics Program Review Meeting

Denver, Colorado

September 8-11, 1998

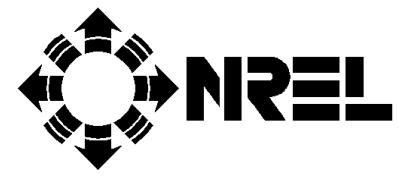

National Renewable Energy Laboratory 1617 Cole Boulevard

Golden, Colorado 80401-3393

A national laboratory of the U.S. Department of Energy Managed by Midwest Research Institute for the U.S. Department of Energy under contract No. DE-AC36-83CH10093

Work performed under task number PV807401

October 1998 


\begin{abstract}
NOTICE
This report was prepared as an account of work sponsored by an agency of the United States government. Neither the United States government nor any agency thereof, nor any of their employees, makes any warranty, express or implied, or assumes any legal liability or responsibility for the accuracy, completeness, or usefulness of any information, apparatus, product, or process disclosed, or represents that its use would not infringe privately owned rights. Reference herein to any specific commercial product, process, or service by trade name, trademark, manufacturer, or otherwise does not necessarily constitute or imply its endorsement, recommendation, or favoring by the United States government or any agency thereof. The views and opinions of authors expressed herein do not necessarily state or reflect those of the United States government or any agency thereof.
\end{abstract}

Available to DOE and DOE contractors from:

Office of Scientific and Technical Information (OSTI)

P.O. Box 62

Oak Ridge, TN 37831

Prices available by calling 423-576-8401

Available to the public from:

National Technical Information Service (NTIS)

U.S. Department of Commerce

5285 Port Royal Road

Springfield, VA 22161

703-605-6000 or 800-553-6847

or

DOE Information Bridge

http://www.doe.gov/bridge/home.html 


\title{
Photovoltaics for Buildings: Key Issues in Pursuit of Market Readiness
}

\author{
Sheila J. Hayter, P.E. \\ National Renewable Energy Laboratory, 1617 Cole Blvd., Golden, CO 80401
}

\begin{abstract}
The photovoltaic (PV) industry is rapidly beginning to recognize the market potential of the buildings sector. New PV-for-buildings products have recently become commercially available, and numerous products that are under development will be introduced within the next 5 years. To ensure that these new products will be adopted and used in common building practices, the PV industry should recognize and address important buildings industry issues. These issues include building codes and standards, after-market servicing, education, and warranties and insurance policies. Photovoltaic systems are also still very expensive. The simplest method for increasing their value for a building is to decrease the building's electrical loads through energy efficiency and conservation. Meeting these goals can only be accomplished through partnerships with the U.S. Department of Energy (DOE), private industry, and public institutions.
\end{abstract}

\section{INTRODUCTION}

When terrestrial applications of PV-produced power first became viable, the use of this power centered on large-scale utility electrical production. Photovoltaic cell, module, and system technology rapidly developed to optimize PV system performance - assuming the PV arrays could be positioned at the optimal angle and were located where the solar resource was the highest. As the technology began to mature, the PV industry looked to expand to new markets. It was soon discovered that the buildings sector was a huge, untapped market for distributed PV systems.

Residential and commercial buildings consume one-third of the total energy consumed annually in the United States (33.72 out of 94.21 quadrillion Btu in 1997, Figure 1). Residential and commercial end users are responsible for approximately two-thirds of the total annual revenues from electricity production (6.78 out of 10.65 quadrillion Btu in 1997, Figure 2). The buildings sector represents a huge electrical market that presently meets its electrical needs primarily with power produced from burning fossil fuels (Figure 3). Note that one quadrillion Btu is equivalent to 293 million $\mathrm{kWh}$. 


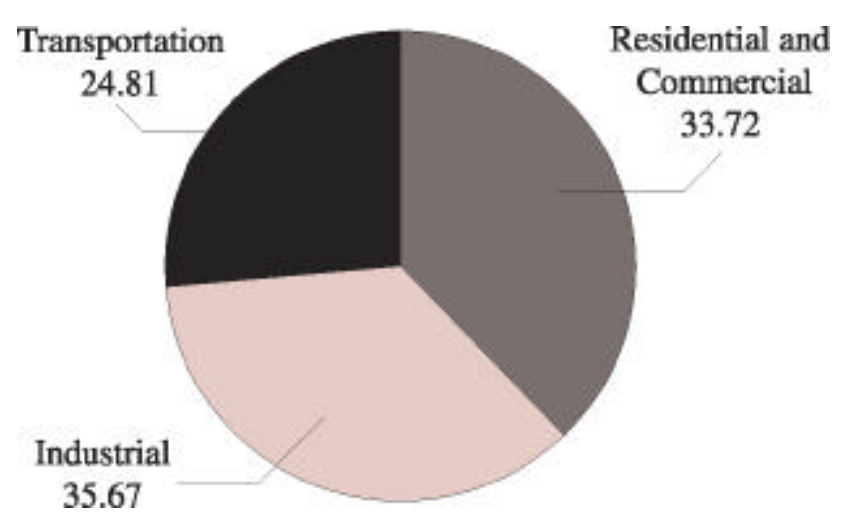

FIGURE 1. 1997 energy flow in quadrillion Btu (1)

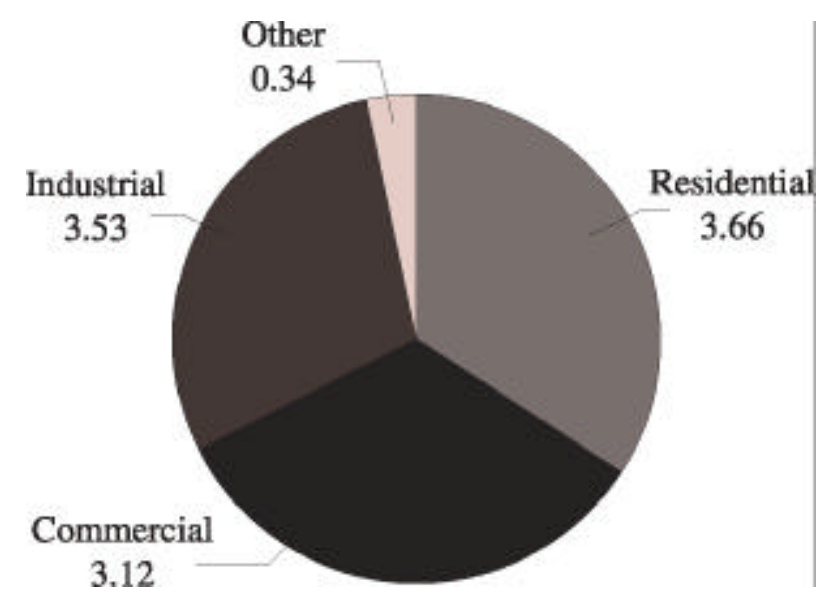

FIGURE 2. 1997 electricity end use flow in quadrillion Btu (1)

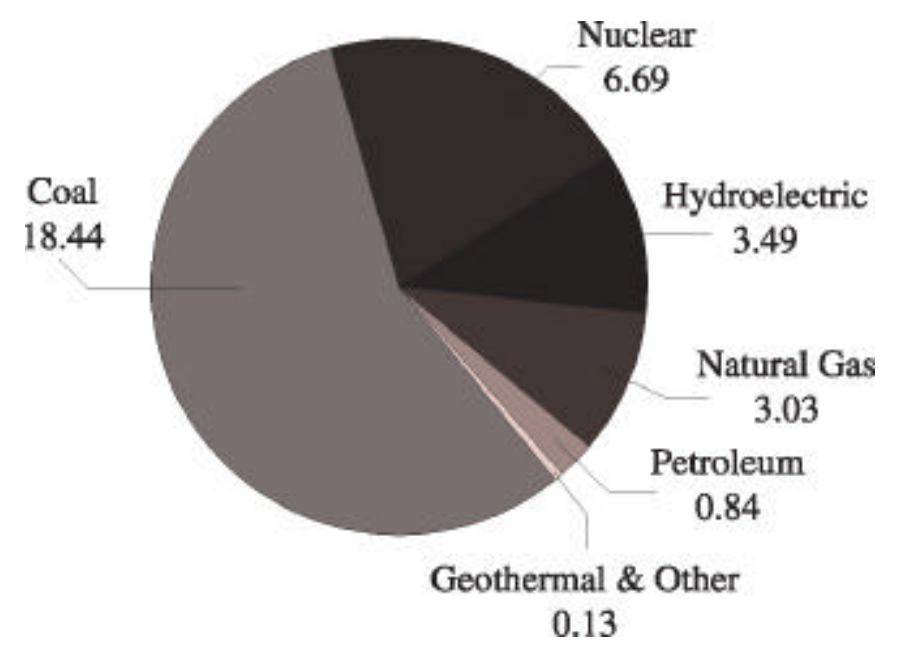

FIGURE 3. 1997 energy consumed to generate electricity in quadrillion Btu (1) 
It is generally accepted by the PV industry that there is growth potential within the buildings sector. Terminology referring to PV systems in buildings, such as building-integrated photovoltaics (BIPV) and PV for buildings, has entered into everyday language of the PV industry over the last several years. But what do these terms mean? Building-integrated PV often refers to the integration of photovoltaic systems into the envelope of a building. In BIPV systems, the PV panels replace part of the building skin such as roof materials, glazings (e.g., windows and skylights), and wall components. PV-for-buildings systems include more than just replacing envelope components. These systems may directly operate systems for air movement (fans), fluid movement (pumps), or provide power for "active" windows (electrochromic windows). Hybrid functions include operating heating, ventilating, and airconditioning (HVAC) systems or lighting systems. Finally, PV-for-buildings systems can be tied with building control systems to reduce building peak electrical demand and ultimately lower customer utility bills. These and other benefits of BIPV and PVfor-buildings systems are outlined in Table 1.

For the PV industry to take advantage of the potential growth provided by the buildings sector, it is important to understand electricity consumption trends within the sector. Figure 4 shows that nearly half of the electricity consumed by all buildings is needed for lighting systems. Cooling systems and office equipment power consumption are the next most electricity-intensive categories, but each only requires approximately $25 \%$ of that consumed by lighting systems. Additional trends appearing when considering only commercial buildings are that the most electricityintensive commercial building types are office buildings and mercantile buildings (Figure 5).

TABLE 1. - Benefits of PV-for-Buildings Systems

\begin{tabular}{ll}
\hline Benefit & Description \\
\hline Market growth & $\begin{array}{l}\text { Building market is large, provides significant growth potential for PV } \\
\text { Eliminates T\&D losses }\end{array}$ \\
$\begin{array}{l}\text { PV-for-buildings systems provide power at the point of use and } \\
\text { eliminates utility transmission and distribution losses }\end{array}$ \\
$\begin{array}{l}\text { BIPV offsets costs } \\
\begin{array}{l}\text { Land and support structure } \\
\text { not needed }\end{array}\end{array}$ & $\begin{array}{l}\text { Land and support structure are unnecessary when system is integrated } \\
\text { into the building skin }\end{array}$ \\
$\begin{array}{l}\text { Less cost justification } \\
\text { needed for some BIPV } \\
\text { systems }\end{array}$ & $\begin{array}{l}\text { Architectural elements have fewer cost constraints; building image } \\
\text { enhanced by PV }\end{array}$ \\
$\begin{array}{l}\text { Lowers building peak } \\
\text { electrical demand }\end{array}$ & $\begin{array}{l}\text { PV-for-buildings systems offset peak loads because system output } \\
\text { corresponds to typical daily electrical demands }\end{array}$ \\
\hline
\end{tabular}




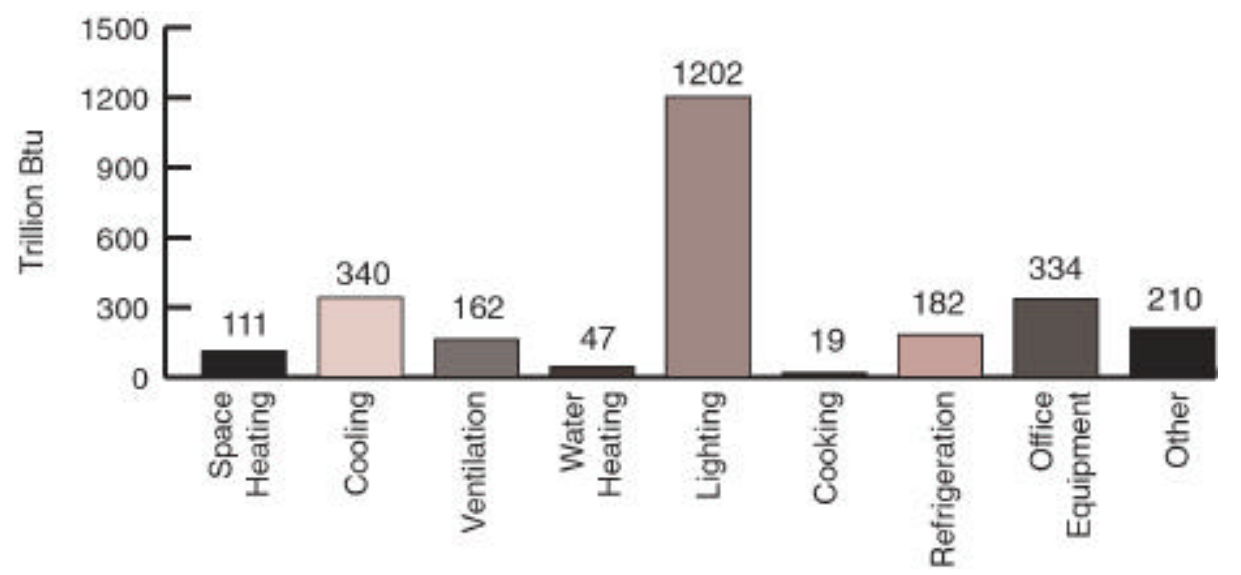

FIGURE 4. 1995 electricity consumption of all buildings (2)

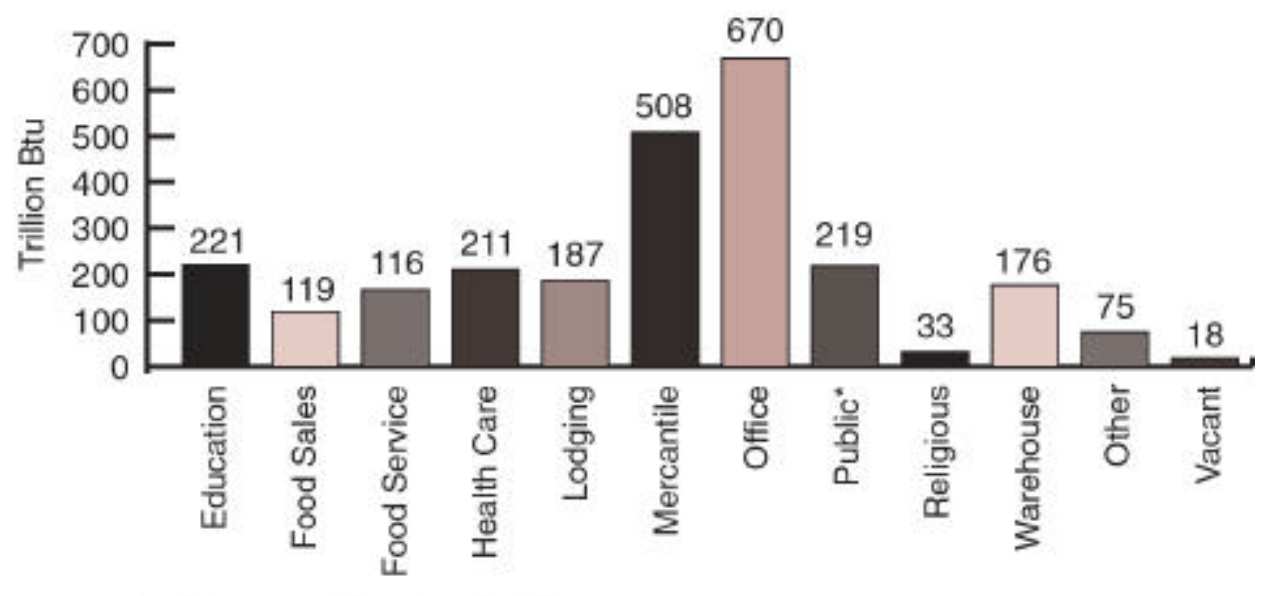

"Includes assembly, order and safety

FIGURE 5. 1995 energy consumption by building type (2)

\section{BUILDINGS-RELATED ISSUES}

The trends and the benefits listed in Table 1 reveal both opportunities for growth and areas that should be of concern to the PV industry. As soon as the PV system is integrated with a building in any way (e.g., replacing building-envelope elements, linked directly to building electrical systems, or mounted on a building structure), it is subjected to the following buildings-related issues.

- Building codes and standards

- Integration issues

- After-market servicing

- Education

- $\quad$ System designers

- System installers 
- Building owners/operators

- Standards and codes developers

- Warranties and insurance policies

- Energy efficiency and conservation.

\section{Building Codes and Standards}

Efforts spearheaded by the National Center for Photovoltaics (NCPV) and individual PV system product manufacturers have successfully influenced electrical codes to address PV systems. For example, article 690 of the National Electric Code (NEC) applies to safety standards for installing PV systems. This article was added to the NEC in 1984 and has been subsequently revised every 3 years. More recently, most PV systems products have begun to undergo testing to be listed by the Underwriters Laboratory. Little effort has been made to evaluate how other nationalconsensus building codes and standards may affect construction of PV-for-buildings systems. Conflicts will arise when existing building codes do not address PV systems in buildings, sometimes making it impossible, or very expensive, to install these systems.

\section{Integration Issues}

It is important to have the buildings industry involved in developing new products and improving existing products. Products introduced to the market that are awkward to integrate with the building envelope or to connect with the building electrical system, and are difficult to maintain, will not be accepted by the buildings industry. The installation, maintenance, and operation of the systems must be acceptable to the construction industry and building operators. The products must also address those areas important to building designers. For example, this includes ensuring that the products do not adversely affect the building thermal loads, and that they can be easily integrated into new and retrofit applications.

\section{After-Market Servicing}

There must be a network of qualified technicians to service PV-for-buildings systems after they have been installed. Lessons learned for the oil embargo era in the 1970s and 80s have taught the solar industry that unless solar systems are reliable and can easily be maintained and serviced, the public will not be interested in investing in these systems. Currently, activities within the NCPV are addressing these issues for the PV system. Not as much emphasis has been given to servicing the integration aspects of the PV system, whether it be to address the integration of the PV system within the building envelope or with the building electrical system. 


\section{Education}

It is the responsibility of the NCPV and the PV industry to educate all the players involved with the design, installation, ownership, and operation of a PV-for-buildings system. Architects and engineers will have the confidence to actually design PV for buildings system after they learn how to design such systems. Members of the construction industry who will be installing various components of the PV-forbuildings systems must understand how to properly install the systems for safety and durability. Building owners should understand the benefits and risks involved with owning these systems. Building operators must know how to optimize the PV-forbuildings system performance and be familiar with proper maintenance of the systems. Finally, those responsible for developing building codes and standards need to know how to address PV-for-buildings systems.

\section{Warranties and Insurance Policies}

Providing warranties for the entire PV-for-buildings system (not just the PV component) will build customer confidence in taking the risk to purchase what is still considered in the buildings industry a new technology. Warranties will also encourage insurance companies to insure these systems. This is analogous to offering insurance on an automobile where the automobile is a single unit comprised of many components. Individual components also have different life expectancies. For example, the electronics or balance of system components often have shorter life times than the PV modules. This must be taken into consideration when establishing warranties for the entire system. By offering warranties and insurance on the systems, more consumers will risk purchasing new PV-for-buildings products and integrating them into new and retrofit building designs.

\section{Energy Efficiency and Conservation}

Photovoltaic systems are still expensive - too expensive for most building owners to consider. Some credit can be applied to BIPV systems for the envelope component the PV system is replacing. However, only high-end, architectural components such as fritted glass have costs comparable to the cost of PV systems. Especially in residential applications, the cost of building materials such as asphalt shingles is insignificant compared to PV systems.

In today's market, the simplest method for justifying the cost of a PV system is to increase its effect on the total energy consumption of a building. This increased effect is achieved not by increasing the capacity of the PV system, but by decreasing the building's electrical load. A building's electrical load is decreased through energy- 
efficient building design using passive solar design strategies (e.g., daylighting to reduce lighting loads, building orientation to reduce solar gains/cooling loads), use of energy-efficient appliances and equipment, and optimizing the control of the electrical loads. Photovoltaic systems can also be used to decrease a building's peak electrical demand. In many cases, decreasing the demand saves enough in utility demand changes to justify the cost of the PV system. Developing an understanding between the PV and buildings industries is needed to achieve low-energy building design that will increase the positive effects of the PV system on meeting the building's electrical requirements.

\section{SUMMARY}

The PV industry has been extremely active in developing new PV-for-buildings products and introducing those products to the market. Since the mid-1990s, PVshingles resembling asphalt shingles or roof slates, PV modules to match standingseam metal roofing, curtain wall PV modules, architecturally flexible overheadglazing PV modules, and insulated PV modules and PV-roof membranes for commercial-building, flat-roof retrofits are all available to building designers. Currently under development are PV-controlled electrochromic windows, thin-film PV modules in which the building designer can specify its transmisivity, and PV/solar thermal hybrid modules. These examples represent only some of the recently available or soon-to-appear products introduced by U.S. PV product manufacturers.

The buildings industry is conservative and slow to change and customers are not willing to risk the financial investment of a PV system without reassurance that they are spending their money wisely. It is important that the PV industry is aware of this sentiment and tries to accommodate the needs of the buildings industry as best as possible when introducing new products.

\section{ACKNOWLEDGEMENTS}

Support for the Photovoltaics for Buildings Task is provided to the National Renewable Energy Laboratory by the U.S. Department of Energy's Office of Utility Technology. Robert Hassett is the program manager.

\section{REFERENCES}

(1) Energy Information Administration (EIA), U.S. Department of Energy. Data obtained from the EIA Web site, “Annual Energy Review, 1997.” <http://www.eia.doe.gov/emeu/aer/>. 3 September 1998.

(2) Energy Information Administration (EIA), U.S. Department of Energy. Data obtained from the EIA Web site, “Annual Energy Review, 1997." <http://www.eia.doe.gov/emeu/consumption/>. 3 September 1998. 